\title{
Genetic characterization and plasmid profile of extended- spectrum $\beta$-lactamase and Quaternary ammonium compound $E$ delta 1 gene producing multi-resistant Shigella species isolated from raw cow milk and milk products in Egypt
}

\author{
Rasha Elkenany \\ Mansoura University Faculty of Veterinary Medicine \\ Rasha Eltaysh \\ Mansoura University Faculty of Veterinary Medicine \\ Mona Elsayed ( $\nabla$ dr.monamohy@yahoo.com ) \\ Mansoura University Faculty of Veterinary Medicine \\ Mohamed Abdel-daim \\ Suez Canal University Faculty of Veterinary Medicine
}

Research article

Keywords: Shigella species, antibiotic resistance, $\beta$-lactamase encoding genes, qacE $\Delta 1$ gene, plasmid profile, dairy products

Posted Date: July 18th, 2019

DOI: https://doi.org/10.21203/rs.2.11541/v1

License: (c) (i) This work is licensed under a Creative Commons Attribution 4.0 International License. Read Full License 


\section{Abstract}

Background Multi-resistant Shigella species recovered from raw cow milk and milk products has predominated all over the world especially extended spectrum $\beta$-lactamases (ESBLs) and Quaternary ammonium compound E delta 1 (qacE $\Delta 1$ ) genes. This study was conducted to investigate the prevalence, antibiotic and disinfectant resistance phenotypes and genotypes as well as plasmid profiles of Shigella species isolated from raw cow milk and milk products in Egypt. The genotypic analysis was determined for the presence of $\beta$-lactamase encoding genes (blaTEM, blaCTX-M, blaOXA-1 and blaSHV), tetA(A) and qacE $\Delta$. Results Twenty-one (7\%) of Shigella isolates (S. dysenteriae, S. flexneri and S. sonnei) were recovered with S. dysenteriae as the most predominant types. Antibiotic sensitivity tests showed $71.4 \%$ of multidrug-resistant Shigella isolates. High resistance rates were observed to tetracyclines (100\%), ampicillin, amoxicillin-clavulanate (90.5\%, each) and cefaclor (66.7\%), whilst no resistance was detected against imipenem, sulfamethoxazole/trimethoprim, and azithromycin. Disinfectant susceptibility test of Shigella isolates revealed resistance to phenolic compound (vanillic), while $85.7 \%$ of Shigella isolates were benzalkonium chloride resistant. Uniplex PCR analysis exhibit presence of $\beta$-lactamase encoding genes (blaTEM in all isolates and blaCTX-M in $28.6 \%$ of isolates), tet $A(A)$ in all isolates and $85.7 \%$ isolates positive for qacE $\Delta 1$, while all isolates were negative for blaOXA-1 and blaSHV. All Shigella extended spectrum $\beta$-lactamase (ESBL) producers $(6,100 \%)$ were positive for blaTEM, blaCTX-M, and qacE $\Delta 1$ genes. Furthermore, plasmid profiling revealed seven distinct plasmid patterns (P1-P7) ranging from 1.26 to $33.61 \mathrm{~kb}$ among all Shigella strains; S. dysenteriae displayed the greatest variance. The co-transfer of $\beta$-lactamase genes (blaTEM and blaCTX-M) and qacE $\Delta 1$ genes was observed by conjugation. Conclusions $\mathrm{S}$. dysenteriae was the most common identified types in the examined sources. Also, the findings imply the emergence of multi-resistant Shigella species either multi-resistant to antibiotics (particularly ESBL producer strains) or disinfectants in Egypt. Thus, the resistance of Shigella species should regularly be monitored and appropriate measures should be taken to manage this problem.

\section{Background}

Shigella species infection is known as the main cause of bacillary dysentery disease which associated with high morbidity and mortality especially in developing countries, such as Egypt [1]. Shigella genus is classified into four species: $S$. dysenteriae, $S$. flexneri, S. boydii, and S. sonnei. Endemic shigellosis in developing countries is mainly occurred by $S$. flexneri but $S$. sonnei is commonly detected in industrialized countries [2]. Dairy products especially raw milk and unpasteurized cheese remain important vehicles for the transmission of Shigella to humans $[3,4]$.

Antibiotic therapy for Shigella infection can decrease the extent and seriousness of the disease [5]. The consequence of the misuse of antibiotics administration, the multi-resistant (MR) Shigella has predominated all over the world, particularly extended spectrum $\beta$-lactamases (ESBLs) which is one of the greatest extended resistance mechanisms [6,7]. There were many ESBL variants known in a variety of pathogens, blaCTX-M, blaTEM, SHV and blaOXA-1 that were proved to be the most successful in terms of antibiotic resistance and for epidemiological niches [7]. Among blaTEMESBLs types,the blaTEM-1 is the most commonly plasmid-mediated $\beta$-lactamase of ampicillin resistant Gram-negative bacteria [8]. The selection of antibiotic treatment for shigellosis becomes more difficult as a result of the generation of Shigella spp. resistance, especially the resistance which was developed to the third-generation cephalosporins which is a common public health problem, mainly in developing countries $[9,10]$. The evolution of multidrug-resistant (MDR) strains is commonly due to the existence of mobile genetic elements such as; plasmids, integrons, and transposons which assist the Shigella spp. to obtain and transfer the exogenous genes [11]. Antibiotic-resistance plasmids often include genes conveying resistance to numerous different antibiotics [12].

Disinfectants including phenolic compound (vanillic) and quaternary ammonium compounds (QACs) such as benzalkonium chloride (BKC) are commonly used in dairy cattle farms. The capability of phenolic compounds to inhibit the growth of any microorganism depends on their interaction with proteins and/or on their membrane-impairing permeability action [13]. A particular concern is that repeated use of disinfectants may cause the persistence of bacteria with reduced susceptibility not only to the antiseptics but possibly to antibiotics [14]. One of the major mechanisms underlying such resistance is the acquisition of resistance genes called qacE and qacE 1 that confer resistance toQACs [15]. The qacE 1 , a mutant version of qacE, is widely distributed throughout gram-negative bacteria mainly in Enterobacteriaceae [16]. 
Multiple global studies have reported the molecular basis of antibiotic resistance in clinical Shigella isolates of human origin[17,18]; but, inadequate data are available on the genotypic and phenotypic characteristics of Shigella spp. isolated from raw cow milk and milk products in Egypt. Therefore, this study was planned to isolate and characterize Shigella from raw milk and milk products in Egypt. This work was also proposed to examine the prevalence of multi-resistant Shigella particularly ESBL producing strains, screen for the presence of $\beta$-lactamase, $\operatorname{tet} A(A)$ and $q a c E \Delta$ 1genes and its plasmid profile.

\section{Results}

The occurrence of Shigella species in raw cow milk and milk products

A total of twenty-one (7\%) organisms were isolated and identified to be Shigella. S. dysentriae was the most frequently identified, comprising12 isolates (57.1\%), followed by S. flexneri with 6 isolates (28.6\%) and S. sonnei with 3 isolates (14.3\%). The occurrences of the isolate in the samples are presented in Table 2. The occurrence of Shigella spp. was higher in kareish cheese $(13 \%)$ than in raw cow's milk (8\%). In addition, the absence of Shigella spp. in all examined yoghurt samples was detected.

\section{Antibiotic and disinfectant susceptibility profiles}

The antibiotic resistance of 21 isolates of Shigella is revealed in Table 3. The highest resistance percentages occurred against tetracyclines (100\%), ampicillin, amoxicillin-clavulanate (90.5\%, each) and cefaclor (66.7\%). The highest frequency of intermediate resistance was displayed against cefaclor (19\%). All isolates were sensitive to imipenem,

sulfamethoxazole/trimethoprim, and azithromycin. The majority of the isolates were sensitive to cefepime, streptomycin (90.5\% each), chloramphenicol (85.7\%), ciprofloxacin (80.9\%), ceftazidime (66.7\%) and cefotaxime (61.9\%). Only one isolate from $S$. dysenteriae and $S$. flexneri yielded resistance to ciprofloxacin and chloramphenicol (9.5\%). Moreover, the only one isolate to display streptomycin resistance was $S$. dysenteriae (4.8\%) but $S$. flexneri (4.8\%) revealed intermediate resistance to streptomycin. About $15(71.4 \%)$ of Shigella isolates were resistant to three of the antimicrobial classes at a minimum. The multidrug antibiotic resistance index (MARI) of the isolates was $0.2-0.5$. The highest MARI of 0.5 was recorded in five (23.8\%) isolates, followed by 0.4 by $4(19 \%)$ isolates, 0.3 by $6(28.6 \%)$ isolates and 0.2 by $6(28.6 \%)$ isolates. The Shigella strains showed eight multi-resistance (MR) phenotypes (Table 4). The predominant MR phenotypes for Shigella isolates were TE, AM, AMC, CEC and TE, AM, AMC in $28.6 \%$ and $19 \%$ of the isolates, respectively. Among all MR phenotypes of Shigella isolates, $23.8 \%$ of them were resistant to six different antibiotics, $19 \%$ to five antibiotics, $28.6 \%$ to 4 antibiotics, $19 \%$ to 3 antibiotics and $9.5 \%$ to 2 antibiotics. The double disk synergy test confirmed that all ceftazidime and cefotaxime resistant strains $(28.6 \%, 3 \mathrm{~S}$. flexneri and 3 S. sonnei) were extended-spectrum $\beta$-lactamase (ESBL) producers.

Concerning the disinfectant resistance (Table 3), there was growth in all plates containing vanillic acid disc that referred to the phenolic compound tolerance of all isolates, while 18 (85.7\%) of Shigella isolates were BKC tolerance.

\section{Characterization of antibiotic and disinfectant resistance genes}

Uniplex PCR assay results exhibited that all Shigella spp. isolates were positive for blaTEM and only 6 (28.6\%) isolates were positive for blaCTX-M, while all Shigella isolates were negative for blaOXA-1 and blaSHV (Table 5) (Figures. S1, S2, S3, S4). Out of 21 Shigella isolates, $6(28.6 \%, 3$ S. flexneri and 3 S. sonnei) isolates were phenotypically considered as ESBLs producers based on cefotaxime and ceftazidime resistance, alone and in combination with clavulanate by double disk synergy test. The genotypic methods demonstrated the existence of the extended-spectrum $\beta$-lactamase-encoding genes in Shigella isolates which were responsible for ESBL production. All Shigella ESBL producers $(6,100 \%)$ were positive for blaTEM and blaCTX-M genes, whilst none of the isolates harbored the blaOXA-1 and blaSHV genes. The tetracycline resistance gene, $\operatorname{tet} A(A)$, was identified in all Shigella isolates. Furthermore, 18 (85.7\%) of Shigella isolates possessed quaternary ammonium compound resistance gene (qacE 1 ) (Figure. S5). Association of the occurrence of qacE 1 with the resistance to antibiotics is presented in Table 5 which illustrates that all MR strains harbor qacE 1 gene. In addition, all qacE $\Delta 1$ gene positive strains were blaTEM and $\operatorname{tet} A(A)$ genes positive.

Plasmid profiling and conjugative transfer

Page $3 / 12$ 
Plasmid profiling (PP) revealed seven distinct plasmid patterns (P1-P7) ranging from 1.26 to $33.61 \mathrm{~kb}$ among the Shigella strains; S. dysenteriae yielded the greatest variance (Table 5). All plasmid patterns (P1-P7) were distributed in a similar percentage $(3,14.3 \%)$ among Shigella spp. S. dysenteriae strains involved from two to four plasmids of approximate sizes 1.26 , $2.23,2.36,2.67,4.07,4.66,7.12,8.89,27.51,30.80$ and/ or $33.61 \mathrm{~kb}$. S. flexneri contained from one to three plasmids of approximate sizes $2.23,4.40,18.59$ and/ or $23.28 \mathrm{~kb}$, while $S$. sonnei harbored two, 1.41 and $30.80 \mathrm{~kb}$ plasmid. All ESBL producing strains harbored plasmids with pattern P7 (1.41 and $30.80 \mathrm{~kb})$ as the predominant pattern.

The co-transfer of $\beta$-lactamase genes (blaTEM and blaCTX-M) and qacE 1 geneswas observed by conjugation.

\section{Discussion}

Although milk and milk products have been represented as an important vehicle for the foodborne disease transmission to humans, in developing countries; limited publications were documented shigellosis outbreaks in related to the consumption of milk and milk products. The current study showed a high prevalence of Shigella spp. (7\%) with the predominance of $S$. dysenteriae in comparison to those recorded by Ahmed and Shimamoto [19]who reported thatShigella spp. were detected in $0.5 \%$ of raw cows milk samples and $0.9 \%$ of Kareish cheese samples with $S$. felxeneri as the most predominant isolates. Tambekar and Bhutda[20]detected $8.7 \%$ of S. flexneri in milk product (pedha) samples in India. The high rate of Shigella prevalence in this study might be regarded to poor hygienic measures during milking, processing, preparation, handling, and storage of milk and milk products.

Antibiotic resistance of Shigella spp. from raw milk and milk products samples in this study was compared with previous reports from Egypt to observe the trend in antibiotic resistance keeping in mind that the respective study samples collection. Overall, this study had displayed the entity of warning levels of Shigella spp. resistant to the prevalently used antibiotics (tetracycline, ampicillin, amoxicillin-clavulanate, cefaclor) $[21,22]$. This resistance might be due to the fact of frequently and improperly using such antibiotics either in animal therapy or as a growth promoter in the veterinary context in Egyp. Also, the current study showed reduced susceptibility to cefotaxime, ceftazidime (third-generation cephalosporins) and ciprofloxacin, which were considered as preferable drugs for shigellosis treatment [10]. Thus, the appearance of such resistance would indicate a great challenge for the efficient treatment of shigellosis.

In this study, about $71.4 \%$ of Shigella isolates were multidrug-resistant to at least three of the antimicrobial classes with multidrug antibiotic resistance index (MARI) of 0.2-0.5. In addition, many isolates of Shigella spp. were shown to have MR phenotypes against tetracycline, ampicillin, amoxicillin-clavulanate, and cefaclor pattern. Nearly similarity, the high prevalence of MR Shigella isolates in dairy products (90.9\%) was reported by Ahmed and Shimamoto [19]in Egypt. Therefore, some measures must be considered to confirm that currently available antibiotics remain effective. These measures may include great awareness among the public, healthcare professionals and the food-agriculture sector concerning the importance of the proper use of these medicines.

The presence of Shigella in the analyzed samples was an indicator of poor hygiene and sanitation during milking, post-milking and during milk processing. The effectiveness of the disinfection depended on the use of suitable disinfectant which was considered from the most critical points of hygienic measures in dairy cattle farms. The phenolic compounds and benzalkonium chloride (BKC) were widely used as farm disinfectant due to their antimicrobial activity [23]. BKC is a cationic, surface-active QAC commonly used as a farm disinfectant for cleaning and sanitizing of livestock buildings, equipment, milk utensils, and vehicle. The present study exhibited that all the tested strains were resistant to phenolic compound, while $85.7 \%$ of isolates were BKC resistance. Similarly, Bouzada et al. [24]found that Gram-negative rods involving Enterobacteriaceae were less susceptible to BKC. Moreover, this work displayed that most of the Shigella isolates (85.7\%) had qacE 1 gene.

There are various $\beta$-lactamases, which hydrolyses the $\beta$-lactam ring and thereby inactivate the antibiotic, have been described, but TEM-, OXA-, SHV-and CTX-M-type $\beta$-lactamases are dominant in the Gram-negative bacteria [25]. Thus, in this investigation, the presence of these $\beta$-lactamase-encoding genes in isolates was recognized by molecular methods, which provided data to support the current study. The blaTEM, a narrow-spectrum $\beta$-lactamase gene, which conveys resistance to penicillins and firstgeneration cephalosporins, was identified in all isolates. Also, the extended spectrum $\beta$-lactamase-encoding genes blaCTX-

Page $4 / 12$ 
Mwas identified in $28.6 \%$ of the isolates. The high incidence of $\beta$-lactamase-encoding genes (blaTEM-1, blaCTX-M, in 2 isolates, blaOXA, in 4 isolates) had been detected previously in Shigella strains isolated from dairy products in Egypt [19]. The blaTEMgene was the dominant $\beta$-lactamase gene in Shigella spp. in this work, while blaCTX-Mwas the most common types of cefotaximases identified among Shigella isolates in the previous study [9].

Alarmingly, in this research, the prevalence of ESBL producing Shigella isolates, accounting for $28.6 \%$ of all Shigella isolates, was higher than detecting rates observed in other countries such as England [26]. This discrepancy between such finding and previous studies might be attributed to the misuse of antibiotics during the treatment of bacterial infections. In addition, the high tetracycline resistance in all Shigella isolates might be described by the potential distribution of the $\operatorname{tet} A(A)$ resistance gene [27].

For epidemiological investigations of various enteric pathogens, plasmid profiling could be an attractive tool. Shigella usually harbor various plasmids that might be from 2 to 10 plasmids in one strain. These plasmids were required for antibiotic resistance and also for invading of bacteria into the epithelial cells of the intestine [28]. Seven Plasmid Patterns, with relative plasmid sizes ranging from 1.26 to $33.61 \mathrm{~kb}$, were detected in this study. It had been reported earlier that Shigella species had numbers of plasmids with a heterogeneous combination ranging from 1.0 to $120 \mathrm{MDa}$ in Egypt [29]. Also, some of the plasmid sizes documented among the Shigella isolates were previously reported in Egypt and other countries [30,31,32]. All MR strains particularly ESBL producing strains carried plasmids with pattern P7 as the predominant pattern in this study. The ESBL encoding gene (blaCTX-M) had been conveyed to plasmid more than other Class A $\beta$-lactamases [33]. The conjugation experiment results assisted the plasmid location of blaTEM, blaCTX-M, and qacE 1 genes, since transconjugants of MR phenotypes of Shigella isolates were done on MacConkey agar. Of the 12 S. dysenteriae isolates in this work, 75\% contained large plasmids, which were associated with antibiotic resistance. Over the last half-century, the extraordinary ability of different isolates in acquiring plasmid-encoded resistance to the disinfectants and antibiotics such as ESBLs, that could quickly be transmitted to several other strains,had demonstrated [34,35].

Antibiotics and disinfectants had been commonly used in dairy farms in Egypt. However, the susceptibility of Shigella to disinfectant and its contribution to multidrug resistance phenotype and genotype by co-selection of plasmid had never been reported. Plasmid-mediated multidrug resistance should be considered for dealing with infectious diseases. Therefore, this work was planned to explore the link between qacE 1 gene, plasmid, and antibiotic resistance. The results of this study showed that all qacE $\triangle$ 1gene positive strains were multi-resistant and plasmid harbored. Recently, it was demonstrated that the qacC gene conveys resistance to a number of $\beta$-lactam antibiotics [36]. While it was found the ability of qac genes to directly acquire resistance to antibiotics. This indicated the close relationship between the resistance to antibiotics and antiseptics [37]. An approaching interdependence between resistance to antiseptics and antibiotics might be principally elucidated by the fact that genetic determinants of resistance to these agents were mainly associated. The plasmids frequently conveyed qac genes with a number of other antibiotic resistance genes $[38,39]$. The plasmid analysis and conjugation experiments showed that the isolates harbored variable detectable plasmids and the antibiotic and disinfectant resistance genes could be co-transferred. This indicated that the resistance was plasmid-mediated, so there was a high risk for the spread of antibiotic and disinfectant resistance genes among the bacteria.

Limitations

The limitations of this study should be mentioned. Although this work explored for the first time the relationship of resistance to antibiotics and disinfectants with plasmids in multi-resistant Shigella spp. in Egypt, it focused on raw cow milk and milk product samples collected from only one province of Egypt and didn't elucidate such relationship in other provinces. Therefore, additional studies are warranted to explore such relationship in other provinces of Egypt.

\section{Conclusion}

This study demonstrated the prevalence of multi-resistant Shigella species either multi-resistant to antibiotics (particularly ESBL producer strains) or disinfectants in raw cow milk and milk products in Egypt that causes a possible hazard to public health and difficulty in controlling of outbreaks. Thus, the resistance of Shigella species should regularly be monitored and appropriate 
measures should be taken to avoid the emergence and spreading of multi-resistant strains. Also, strict hygienic measures must be applied to prevent infection through consumption of dairy products.

\section{Methods}

\section{Sample collection and microbial analysis}

A total of 300 dairy product samples (100 raw cow milk, 100 Karish cheese, and 100 yoghurts) were collected randomly from different dairy farms, shops, and supermarkets in Dakahlia Governorate, Egypt throughout 2018. After collecting samples, they were stored at $4^{\circ} \mathrm{C}$ until examination (within 3-4 h), then homogenization of (25 ml or gm) from each has been done in $225 \mathrm{ml}$ of $0.1 \%$ buffered peptone water (Oxoid, England) by shaking for $5 \mathrm{~min}$ in a sterile stomacher bags and incubating for $24 \mathrm{~h}$ at $44^{\circ} \mathrm{C}$ and $42^{\circ} \mathrm{C}$ for Shigella sonnei and other Shigella species, respectively for recovery. A loop from the enriched cultures was directly inoculated onto Selenite F broth, then subcultured to Salmonella-Shigella (S-S) agar, MacConkey agar and xylose-lysinedeoxycholate agar (XLD) (Oxoid, UK) and then incubated at $37^{\circ} \mathrm{C}$ for $24 \mathrm{~h}$. The presumptive Shigella isolates (colorless, non lactose fermenting on SS agar, white and translucent on MacConkey and pink to red colonies on XLD) were biochemically confirmed by triple sugar iron agar (TSI), lysine iron agar (LIA), methyl red (MR), Voges-Proskauer (VP) broth, indole test, urea agar (UA), Simmon's citrate agar (SCA) and motility test. Serotypes of isolates were determined by slide agglutination assays, using a commercially available kits as described by the manufacturer (Difco Laboratories). All bacterial isolates were stored in tryptic soy broth (TSB) containing $25 \%$ glycerol at $-80^{\circ} \mathrm{C}$ for further analysis.

\section{Antibiotic resistance evaluation}

The antibiotic susceptibility testing was performed using the disk diffusion method according to the standards and interpretative rules described by the guideline of Clinical and Laboratory Standards Institute [40]on Mueller-Hinton agar (Difco). Shigella spp. were tested for susceptibility to commercially available antibiotic disks (Oxoid, England), including: tetracycline

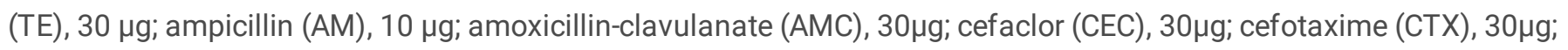

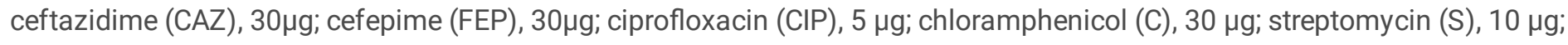

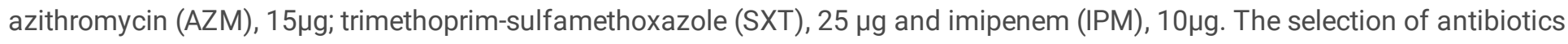
was depended on the frequency and availability of using these antibiotics in the study area, both in veterinary and human medicine. Resistance to at least one antibiotic belonging to at least three antibiotic classes was interpreted as multidrug resistance (MDR). According to the diameter of the inhibition zones, isolates were categorized as sensitive, intermediate, or resistant. The isolates were screened for ESBL production by using the double disk synergy test following recommendation and interpretations of CLS/ standards [40]. Escherichia coli ATCC 25922 was used as quality reference strains. Multiple antibiotic resistance indexes (MARI) was calculated using the formula: $a / b$ where ' $a$ ' represents the number of antibiotics to which a particular isolate was resistant and 'b' the total number of antibiotics tested.

\section{Disinfectant susceptibility testing}

To test the effectiveness of BKC (2\%) [41] and phenolic compound (vanillic 5\%) (Chemica Company) against Shigella isolates, disk diffusion assay was carried out according to the CLSI [42]. Briefly, 24-48 h incubated Shigella broth cultures of each strain were diluted in saline ( $\mathrm{NaCl} 0.9 \%$ ) to contain approximately $1 \times 10^{6} \mathrm{CFU} / \mathrm{ml}$ by McFarland turbidity standards, the diluted cultures were poured on the surface of nutrient agar plates. The plates were allowed to dry after which five assay disks, $6 \mathrm{~mm}$, saturated with test substances which were applied to the surface of each plate then incubated aerobically at $37^{\circ} \mathrm{C}$ for $24 \mathrm{~h}$. The sensitivity pattern was scored as tolerance (-) and sensitive (+).

\section{Screening for antibiotic and disinfectant resistance genes}

For amplification of $\beta$-lactamase-encoding genes (blaTEM, blaCTX-M, blaOXA-1, and blaSHV), tetracycline genes and quaternary ammonium compound resistance genes ( $q a c E \Delta 1$ ), uniplex PCR assays were applied with primers provided by Metabion (Germany) (Table 1). These resistance genes were mostly encoded in Gram-negative bacteria. Shigella isolates chromosomal DNA was extracted by the QIAamp DNA Mini kit (Qiagen, Germany, $\mathrm{GmbH}$ ) considering modulations from the manufacturer's 
recommendations. The PCR amplification reaction was carried out in an applied biosystem 2720 thermal cycler using specific profiles (Table 1). The PCR products were subjected to electrophoresis in 1.5\% agarose gel (Applichem, Germany, GmbH) in 1x TBE buffer using gradients of $5 \mathrm{~V} / \mathrm{cm}$. After staining with ethidium bromide the gel was visualized under UV light.

Plasmid profile analysis and Conjugative transfer

Plasmid Midi kits (Qiagen, Germany, GmbH) were used for plasmid DNA isolation from clinical isolates. Gel electrophoresis of the PCR products was applied to $0.8 \%$ agarose gel (Applichem, Germany, $\mathrm{GmbH}$ ). The fragment sizes were determined by a gene ruler $1 \mathrm{~Kb}$ plus DNA ladder (Fermentas, Thermo Scientific, Germany). In a trial to prove the association of these plasmids with ESBL antibiotic resistance, conjugation experiments were carried out as described previously [46] using the azide-resistant E. coli $\mathrm{J} 53$ as the recipient strain. Transconjugants were detected by plating mating mixtures on MacConkey agar supplemented with $150 \mathrm{mg} / \mathrm{L}$ sodium azide and $2 \mathrm{mg} / \mathrm{L}$ cefotaxime. Co-transfer of resistance determinants was determined through amplification of the relevant genes in the transconjugants.

\section{Abbreviations}

S:Shigella; ESBLs:extended spectrum $\beta$-lactamases; QacE $\Delta$ 1:Quaternary ammonium compound E delta 1 gene; MR:multiresistant; MDR: multidrug-resistant; QACs:quaternary ammonium compounds; BKC:benzalkonium chloride; MARI:multidrug antibiotic resistance index; AM:ampicillin; AMC:amoxicillin-clavulanate; CEC:cefaclor ; CTX:cefotaxime; CAZ:ceftazidime; FEP:cefepime; CIP:ciprofloxacin; C:chloramphenicol; S:streptomycin; AZM:azithromycin; SXT:trimethoprim-sulfamethoxazole; IPM:Imipenem (IPM), PCR:polymerase chain reaction; PP:Plasmid profiling; S-S:Salmonella-Shigella agar; XLD:xylose-lysinedeoxycholate agar; TSI:triple sugar iron agar, LIA:lysine iron agar; MR:methyl red, VP:Voges-Proskauer broth, UA:urea agar, SCA:Simmon's citrate agar; TSB:tryptic soy broth.

\section{Tables}

Table 1. PCR conditions employed for the detection of resistance associated genes of Shigella 


\begin{tabular}{|c|c|c|c|c|c|c|c|c|}
\hline \multirow{2}{*}{$\begin{array}{l}\text { Target } \\
\text { gene }\end{array}$} & \multirow[t]{2}{*}{ Primers sequences } & \multirow{2}{*}{$\begin{array}{l}\text { Amplified } \\
\text { segment } \\
\text { (bp) }\end{array}$} & \multirow{2}{*}{$\begin{array}{c}\text { Primary } \\
\text { denaturation }\end{array}$} & \multicolumn{3}{|c|}{ Amplification (35 cycles) } & \multirow{2}{*}{$\begin{array}{c}\text { Final } \\
\text { extension }\end{array}$} & \multirow[t]{2}{*}{ Reference } \\
\hline & & & & $\begin{array}{l}\text { Secondary } \\
\text { denaturation }\end{array}$ & Annealing & Extension & & \\
\hline \multirow[t]{2}{*}{ blaTEM } & ATCAGCAATAAACCAGC & \multirow[t]{2}{*}{516} & \multirow{2}{*}{$\begin{array}{l}94^{\circ} \mathrm{C} \\
5 \mathrm{~min} .\end{array}$} & \multirow{2}{*}{$\begin{array}{l}94^{\circ} \mathrm{C} \\
30 \mathrm{sec} .\end{array}$} & \multirow{2}{*}{$\begin{array}{l}54^{\circ} \mathrm{C} \\
45 \mathrm{sec} .\end{array}$} & \multirow{2}{*}{$\begin{array}{l}72^{\circ} \mathrm{C} \\
45 \mathrm{sec} .\end{array}$} & \multirow{2}{*}{$\begin{array}{l}72^{\circ} \mathrm{C} \\
10 \mathrm{~min} .\end{array}$} & \multirow{6}{*}{$\begin{array}{l}\text { Colom et al. } \\
\qquad \text { [43] }\end{array}$} \\
\hline & CCCCGAAGAACGTTTTC & & & & & & & \\
\hline \multirow[t]{2}{*}{ blaOXA- } & АTATCTCTACTGTTGCATCTCC & \multirow[t]{2}{*}{619} & \multirow{2}{*}{$\begin{array}{l}94^{\circ} \mathrm{C} \\
5 \mathrm{~min} .\end{array}$} & \multirow{2}{*}{$\begin{array}{c}94^{\circ} \mathrm{C} \\
30 \mathrm{sec} .\end{array}$} & \multirow{2}{*}{$\begin{array}{l}54^{\circ} \mathrm{C} \\
45 \mathrm{sec} .\end{array}$} & \multirow{2}{*}{$\begin{array}{l}72^{\circ} \mathrm{C} \\
45 \mathrm{sec} .\end{array}$} & \multirow{2}{*}{$\begin{array}{l}72^{\circ} \mathrm{C} \\
10 \mathrm{~min} .\end{array}$} & \\
\hline & AАAСССТТСАААССАТСС & & & & & & & \\
\hline \multirow[t]{2}{*}{ blasHV } & AGGATTGACTGCCTTTTTG & \multirow[t]{2}{*}{392} & \multirow{2}{*}{$\begin{array}{l}94^{\circ} \mathrm{C} \\
5 \mathrm{~min} .\end{array}$} & \multirow{2}{*}{$\begin{array}{l}94^{\circ} \mathrm{C} \\
30 \text { sec. }\end{array}$} & \multirow{2}{*}{$\begin{array}{l}54^{\circ} \mathrm{C} \\
45 \mathrm{sec} .\end{array}$} & \multirow{2}{*}{$\begin{array}{r}72^{\circ} \mathrm{C} \\
45 \text { sec. }\end{array}$} & \multirow{2}{*}{$\begin{array}{l}72^{\circ} \mathrm{C} \\
10 \mathrm{~min} .\end{array}$} & \\
\hline & ATTTGCTGATTTCGCTCG & & & & & & & \\
\hline \multirow{3}{*}{$\begin{array}{c}\text { bla }_{\text {CTX- }} \\
\text { M }\end{array}$} & ATG TGC AGY ACC AGT AAR & \multirow[t]{3}{*}{593} & \multirow{3}{*}{$\begin{array}{l}94^{\circ} \mathrm{C} \\
5 \mathrm{~min} .\end{array}$} & \multirow{3}{*}{$\begin{array}{l}94^{\circ} \mathrm{C} \\
30 \mathrm{sec} .\end{array}$} & \multirow{3}{*}{$\begin{array}{l}60^{\circ} \mathrm{C} \\
45 \mathrm{sec} .\end{array}$} & \multirow{3}{*}{$\begin{array}{l}72^{\circ} \mathrm{C} \\
45 \mathrm{sec} .\end{array}$} & \multirow{3}{*}{$\begin{array}{l}72^{\circ} \mathrm{C} \\
10 \mathrm{~min} .\end{array}$} & \multirow{3}{*}{$\begin{array}{c}\text { Archambault } \\
\text { et al. [44] }\end{array}$} \\
\hline & GTK ATG GC & & & & & & & \\
\hline & $\begin{array}{l}\text { TGG GTR AAR TAR GTS ACC } \\
\text { AGA AYC AGC GG }\end{array}$ & & & & & & & \\
\hline $\operatorname{tet} A(A)$ & GGTTCACTCGAACGACGTCA & 576 & $94^{\circ} \mathrm{C} \quad 5$ & $94^{\circ} \mathrm{C}$ & $50^{\circ} \mathrm{C}$ & $72^{\circ} \mathrm{C}$ & $72^{\circ} \mathrm{C}$ & Randall et \\
\hline & & & min. & $30 \mathrm{sec}$. & 40 sec. & $45 \mathrm{sec}$. & $\begin{array}{l}10 \\
\min \end{array}$ & al. [45] \\
\hline qacE $\Delta 1$ & $\begin{array}{c}\text { TAA GCC CTA CAC } \\
\text { AAA TTG GGA GAT AT }\end{array}$ & 362 & $\begin{array}{l}94^{\circ} \mathrm{C} \\
5 \mathrm{~min} .\end{array}$ & $\begin{array}{l}94^{\circ} \mathrm{C} \\
30 \mathrm{sec} .\end{array}$ & $\begin{array}{l}58^{\circ} \mathrm{C} \\
40 \mathrm{sec} .\end{array}$ & $\begin{array}{l}72^{\circ} \mathrm{C} \\
40 \mathrm{sec} .\end{array}$ & $\begin{array}{l}72^{\circ} \mathrm{C} \\
10 \mathrm{~min} .\end{array}$ & $\begin{array}{c}\text { Chuanchuen } \\
\text { et al. [16] }\end{array}$ \\
\hline & $\begin{array}{c}\text { GCC TCC GCA GCG ACT TCC } \\
\text { ACG }\end{array}$ & & & & & & & \\
\hline
\end{tabular}

Table 2. The occurrence of Shigella species in dairy products $(n=300)$.

\begin{tabular}{|c|c|c|c|c|}
\hline \multirow{2}{*}{ Isolated bacteria } & \multicolumn{3}{|c|}{ No of positive samples (\%) } & \multirow{2}{*}{ Total (n=300) } \\
\cline { 2 - 5 } & Raw cow's milk $(\mathrm{n}=100)$ & Kareish cheese $(\mathrm{n}=100)$ & Yogurt $(\mathrm{n}=100)$ & \\
\hline Shigella dysenteriae & $5(5 \%)$ & $7(7 \%)$ & 0 & $12(57.1 \%)$ \\
\hline Shigella flexneri & $2(2 \%)$ & $4(4 \%)$ & 0 & $6(28.6 \%)$ \\
\hline Shigella sonnei & $1(1 \%)$ & $2(2 \%)$ & 0 & $3(14.3 \%)$ \\
\hline Total & $8(8 \%)$ & $13(13 \%)$ & 0 & $21 / 300(7 \%)$ \\
\hline
\end{tabular}


Table 3. Antibiotic and disinfectant susceptibility profiles of Shigella species $(n=21)$.

\begin{tabular}{|c|c|c|c|c|c|c|c|c|c|c|c|c|c|}
\hline \multirow[t]{2}{*}{$\begin{array}{c}\text { Antimicrobial } \\
\text { class }\end{array}$} & \multirow[t]{2}{*}{ Antimicrobial } & \multicolumn{3}{|c|}{$\begin{array}{c}\text { Shigella } \\
\text { dysenteriae }(\mathrm{n}=12)\end{array}$} & \multicolumn{3}{|c|}{$\begin{array}{c}\text { Shigella } \\
\text { flexneri }(\mathrm{n}=6)\end{array}$} & \multicolumn{3}{|c|}{$\begin{array}{c}\text { Shigella } \\
\text { sonnei }(\mathrm{n}=3)\end{array}$} & \multicolumn{3}{|c|}{ Total $(n=21)(\%)$} \\
\hline & & $\mathbf{R}$ & I & S & $\mathbf{R}$ & I & $\mathbf{S}$ & $\mathbf{R}$ & I & $\mathbf{S}$ & $\mathbf{R}$ & I & S \\
\hline Tetracyclines & $\mathrm{TE}$ & 12 & 0 & 0 & 6 & 0 & 0 & 3 & 0 & 0 & $21(100 \%)$ & 0 & 0 \\
\hline \multirow[t]{2}{*}{ B-lactam } & $\mathrm{AM}$ & 11 & 1 & 0 & 5 & 1 & 0 & 3 & 0 & 0 & $19(90.5 \%)$ & $2(9.5 \%)$ & 0 \\
\hline & AMC & 12 & 0 & 0 & 4 & 1 & 1 & 3 & 0 & 0 & $19(90.5 \%)$ & $1(4.8 \%)$ & $1(4.8 \%)$ \\
\hline \multirow[t]{4}{*}{ Cephalosporines } & CEC & 8 & 2 & 2 & 4 & 1 & 1 & 2 & 1 & 0 & $\begin{array}{l}14(66.7 \\
\%)\end{array}$ & $4(19 \%)$ & $3(14.3 \%)$ \\
\hline & CTX & 0 & 2 & 10 & 3 & 0 & 3 & 3 & 0 & 0 & $6(28.6 \%)$ & $2(9.5 \%)$ & $13(61.9 \%)$ \\
\hline & $\mathrm{CAZ}$ & 0 & 1 & 11 & 3 & 0 & 3 & 3 & 0 & 0 & $6(28.6 \%)$ & $1(4.8 \%)$ & $14(66.7 \%)$ \\
\hline & FEP & 0 & 2 & 10 & 0 & 0 & 6 & 0 & 0 & 3 & 0 & $2(9.5 \%)$ & $19(90.5 \%)$ \\
\hline Fluoroquinolones & CIP & 1 & 2 & 9 & 1 & 0 & 5 & 0 & 0 & 3 & $2(9.5 \%)$ & $2(9.5 \%)$ & $17(80.9 \%)$ \\
\hline Phenicols & C & 1 & 1 & 10 & 1 & 0 & 5 & 0 & 0 & 3 & $2(9.5 \%)$ & $1(4.8 \%)$ & $18(85.7 \%)$ \\
\hline Aminoglycosides & S & 1 & 0 & 11 & 0 & 1 & 5 & 0 & 0 & 3 & $1(4.8 \%)$ & $1(4.8 \%)$ & $19(90.5 \%)$ \\
\hline Macrolides & AZM & 0 & 0 & 12 & 0 & 0 & 6 & 0 & 0 & 3 & 0 & 0 & $21(100 \%)$ \\
\hline Sulfonamides & SXT & 0 & 0 & 12 & 0 & 0 & 6 & 0 & 0 & 3 & 0 & 0 & $21(100 \%)$ \\
\hline Carbapenems & IPM & 0 & 0 & 12 & 0 & 0 & 6 & 0 & 0 & 3 & 0 & 0 & $21(100 \%)$ \\
\hline QAC & BKC & 9 & - & 3 & 6 & - & 0 & 3 & - & 0 & $\begin{array}{l}18 \\
(85.7 \%)\end{array}$ & - & $3(14.3 \%)$ \\
\hline $\begin{array}{l}\text { Phenolic } \\
\text { compound }\end{array}$ & v & 12 & - & 0 & 6 & - & 0 & 3 & - & 0 & 21 (100\%) & - & 0 \\
\hline
\end{tabular}

Resistance (R), Intermediate (I), Sensitive (S), number (n), tetracycline (TE), ampicillin (AM), amoxacillin-clavulanate (AMC), cefaclor (CEC), cefotaxime (CTX), ceftazidime (CAZ), cefepime (FEP), ciprofloxacin (CIP), chloramphenicol (C), streptomycin (S), azithromycin (AZM), trimethoprim sulfamethazole (SXT), imipenem (IPM), quaternary ammonium compound (QAC), benzalkonium chloride (BKC), vanillic (V),

Table 4. The antimicrobial resistance phenotypes of isolated Shigella strains $(n=21)$. 


\begin{tabular}{|c|l|c|c|c|c|}
\hline Pattern & resistance phenotypes & No. of isolates & No. of resistant antibiotics & Ratio (\%) & MARI \\
\hline A & TE,AM,AMC,CEC,CIP,C & 2 & 6 & 9.5 & 0.5 \\
\hline B & TE,AM,AMC,CEC,CTX,CAZ & 3 & 6 & 14.3 & 0.5 \\
\hline C & TE,AM,AMC,CEC,S & 1 & 5 & 4.8 & 0.4 \\
\hline D & TE,AM,CEC,CTX,CAZ & 2 & 5 & 9.5 & 0.4 \\
\hline E & TE,AM,AMC,CTX,CAZ & 1 & 5 & 4.8 & 0.4 \\
\hline F & TE,AM,AMC,CEC & 6 & 4 & 28.6 & 0.3 \\
\hline G & TE,AM,AMC & 4 & 3 & 19 & 0.2 \\
\hline H & TE,AMC & 2 & 2 & 9.5 & 0.2 \\
\hline
\end{tabular}

Multiple antibiotic resistance indexes (MARI) was calculated using the formula: a/b where 'a' represents the number of antibiotics to which a particular isolate was resistant and ' $b$ ' the total number of antibiotics tested.

Table 5. Characteristic features of Shigella species under study $(n=21)$. 


\begin{tabular}{|c|c|c|c|c|c|c|c|c|c|c|c|}
\hline \multirow{3}{*}{$\begin{array}{l}\text { Strain } \\
\text { ID }\end{array}$} & \multirow[t]{3}{*}{ Species } & \multirow[t]{3}{*}{ Resistance Phenotype } & \multicolumn{6}{|c|}{ Resistance genotype } & \multirow{3}{*}{$\begin{array}{l}\text { Plasmid } \\
\text { patterns }\end{array}$} & \multirow[t]{3}{*}{ Plasmid (Kb) } & \multirow[t]{3}{*}{ Source } \\
\hline & & & \multicolumn{4}{|c|}{ ESBL } & \multirow[t]{2}{*}{$\operatorname{Tet}(A)$} & \multirow[t]{2}{*}{ Qac } & & & \\
\hline & & & blaTEM & $\begin{array}{l}\text { blaCTX- } \\
\text { M }\end{array}$ & $\begin{array}{c}\text { blaOXA- } \\
1\end{array}$ & blaSHV & & & & & \\
\hline SD1 & $\begin{array}{c}\text { S. } \\
\text { dysenteriae }\end{array}$ & $\begin{array}{l}\text { TE,AM,AMC,CEC,S, } \\
\mathrm{BKC}, \mathrm{P}\end{array}$ & + & - & - & - & + & + & $\mathrm{P} 1$ & $\begin{array}{l}8.89,4.07 \\
2.23,1.26\end{array}$ & $\begin{array}{l}\text { Raw } \\
\text { milk }\end{array}$ \\
\hline SD2 & $\begin{array}{c}\text { S. } \\
\text { dysenteriae }\end{array}$ & TE,AM,AMC,CEC, BKC,P & + & - & - & - & + & + & $\mathrm{P} 1$ & $\begin{array}{l}8.89,4.07 \\
2.23,1.26\end{array}$ & $\begin{array}{l}\text { Raw } \\
\text { milk }\end{array}$ \\
\hline SD3 & $\begin{array}{c}\text { S. } \\
\text { dysenteriae }\end{array}$ & TE,AMC,P & + & - & - & - & + & - & $\mathrm{P} 1$ & $\begin{array}{l}8.89,4.07 \\
2.23,1.26\end{array}$ & $\begin{array}{l}\text { Raw } \\
\text { milk }\end{array}$ \\
\hline SD4 & $\begin{array}{c}\text { S. } \\
\text { dysenteriae }\end{array}$ & TE,AM,AMC,CEC, BKC,P & + & - & - & - & + & + & P3 & $30.80,7.12$ & $\begin{array}{l}\text { Raw } \\
\text { milk }\end{array}$ \\
\hline SD5 & $\begin{array}{c}\text { S. } \\
\text { dysenteriae }\end{array}$ & TE,AM,AMC,CEC, BKC,P & + & - & - & - & + & + & P3 & $30.80,7.12$ & $\begin{array}{l}\text { Raw } \\
\text { milk }\end{array}$ \\
\hline SD6 & $\begin{array}{c}\text { S. } \\
\text { dysenteriae }\end{array}$ & TE,AM,AMC,CEC, BKC,P & + & - & - & - & + & + & $\mathrm{P} 2$ & $\begin{array}{c}27.51,4.66, \\
2.36\end{array}$ & $\begin{array}{l}\text { Kareish } \\
\text { cheese }\end{array}$ \\
\hline SD7 & $\begin{array}{c}\text { S. } \\
\text { dysenteriae }\end{array}$ & $\begin{array}{l}\text { TE,AM,AMC,CEC,CIP,C, } \\
\text { BKC,P }\end{array}$ & + & - & - & - & + & + & P3 & $30.80,7.12$ & $\begin{array}{l}\text { Kareish } \\
\text { cheese }\end{array}$ \\
\hline SD8 & $\begin{array}{c}\text { S. } \\
\text { dysenteriae }\end{array}$ & TE,AM,AMC,CEC, BKC,P & + & - & - & - & + & + & $\mathrm{P} 4$ & $33.617,2.677$ & $\begin{array}{l}\text { Kareish } \\
\text { cheese }\end{array}$ \\
\hline SD9 & $\begin{array}{c}\text { S. } \\
\text { dysenteriae }\end{array}$ & $\begin{array}{l}\text { TE,AM,AMC, CEC, } \\
\text { BKC,P }\end{array}$ & + & - & - & - & + & + & $\mathrm{P} 2$ & $\begin{array}{c}27.51,4.66, \\
2.36\end{array}$ & $\begin{array}{l}\text { Kareish } \\
\text { cheese }\end{array}$ \\
\hline SD 10 & $\begin{array}{c}\text { S. } \\
\text { dysenteriae }\end{array}$ & TE,AM,AMC,P & + & - & - & - & + & - & $\mathrm{P} 2$ & $\begin{array}{c}27.51,4.66, \\
2.36\end{array}$ & $\begin{array}{l}\text { Kareish } \\
\text { cheese }\end{array}$ \\
\hline SD11 & $\begin{array}{c}\text { S. } \\
\text { dysenteriae }\end{array}$ & TE,AM,AMC,P & + & - & - & - & + & - & $\mathrm{P} 4$ & $33.617,2.677$ & $\begin{array}{l}\text { Kareish } \\
\text { cheese }\end{array}$ \\
\hline SD12 & $\begin{array}{c}\text { S. } \\
\text { dysenteriae }\end{array}$ & TE,AM,AMC, BKC,P & + & - & - & - & + & + & $\mathrm{P} 4$ & $33.617,2.677$ & $\begin{array}{l}\text { Kareish } \\
\text { cheese }\end{array}$ \\
\hline SF1 & S. flexneri & $\begin{array}{l}\text { TE,AM,AMC,CEC,CIP,C, } \\
\text { BKC,P }\end{array}$ & + & - & - & - & + & + & P5 & 18.59 & $\begin{array}{l}\text { Raw } \\
\text { milk }\end{array}$ \\
\hline SF2 & S. flexneri & $\begin{array}{l}\text { TE,AM,AMC,CEC,CTX, } \\
\text { CAZ,BKC,P }\end{array}$ & + & + & - & - & + & + & P6 & $\begin{array}{c}23.28,4.40 \\
2.23\end{array}$ & $\begin{array}{l}\text { Raw } \\
\text { milk }\end{array}$ \\
\hline SF3 & S. flexneri & $\begin{array}{l}\text { TE,AM,CEC,CTX, } \\
\text { CAZ,BKC,P }\end{array}$ & + & + & - & - & + & + & P5 & 18.59 & $\begin{array}{l}\text { Kareish } \\
\text { cheese }\end{array}$ \\
\hline SF4 & S. flexneri & $\begin{array}{l}\text { TE,AM,CEC,CTX, } \\
\text { CAZ,BKC,P }\end{array}$ & + & + & - & - & + & + & P5 & 18.59 & $\begin{array}{l}\text { Kareish } \\
\text { cheese }\end{array}$ \\
\hline
\end{tabular}




\begin{tabular}{|c|c|c|c|c|c|c|c|c|c|c|c|}
\hline SF5 & S. flexneri & TE,AM,AMC, BKC,P & + & - & - & & + & + & P6 & $\begin{array}{c}23.28,4.40, \\
2.23\end{array}$ & $\begin{array}{l}\text { Kareish } \\
\text { cheese }\end{array}$ \\
\hline SF6 & S. flexneri & TE,AMC, BKC,P & + & - & - & - & + & + & P6 & $\begin{array}{c}23.28,4.40, \\
2.23\end{array}$ & $\begin{array}{l}\text { Kareish } \\
\text { cheese }\end{array}$ \\
\hline SS1 & S. sonnei & $\begin{array}{l}\text { TE,AM,AMC,CEC,CTX, } \\
\text { CAZ,BKC,P }\end{array}$ & + & + & - & - & + & + & P7 & $30.80,1.41$ & $\begin{array}{l}\text { Raw } \\
\text { milk }\end{array}$ \\
\hline SS2 & S. sonnei & $\begin{array}{l}\text { TE,AM,AMC,CEC,CTX, } \\
\text { CAZ,BKC,P }\end{array}$ & + & + & - & - & + & + & P7 & $30.80,1.41$ & $\begin{array}{l}\text { Kareish } \\
\text { cheese }\end{array}$ \\
\hline SS3 & S. sonnei & $\begin{array}{l}\text { TE,AM,AMC,CTX, } \\
\text { CAZ,BKC,P }\end{array}$ & + & + & - & - & + & + & P7 & $30.80,1.41$ & $\begin{array}{l}\text { Kareish } \\
\text { cheese }\end{array}$ \\
\hline
\end{tabular}

P; plasmid

\section{Supplemental Figure Legends:}

1. Figure S1. Representative gel showing an amplification of blaTEM gene (516 bp) in Shigella isolates.

2. Figure S2. Representative gel showing an amplification of blaCTX-M gene (593 bp) in Shigella isolates.

3. Figure S3. Representative gel showing an amplification of tetA(A) gene (576 bp) in Shigella isolates.

5. Figure S4. Representative gel showing an amplification of qacE $\Delta 1$ gene (362 bp) in Shigella isolates.

\section{Supplementary Files}

This is a list of supplementary files associated with this preprint. Click to download.

- supplement1.docx 